\title{
Sedimentary Mechanism in the Coal and Oil Shale Bearing Succession Graben Basins: The Comparision between Fushun and Huangxian Basins, Eastern China
}

\author{
Dawei Lv*, Xiaoyan Wu, Zengxue Li, Tingting Feng, Haiyan Liu, Dongdong Wang and \\ Luyang Zhao
}

\author{
Shandong Provincial Key Laboratory of Depositional Mineralization and Sedimentary Minerals, College of Geological \\ Science and Engineering, Shandong University of Science and Technology, Qingdao 266590, China
}

\begin{abstract}
The association of coal and oil shale had been a hot topic for a long time. Various types of association of coal and oil shale can be found in one basin, for instance, the coal can act as the roof or floor or interlayer of the oil shale, etc. The most crucial factor for the formation of oil shale is stratification and seasonal blooming of lower plankton, while the final formation of the coal still needs a hypoxia restored deposition environment. We take Huangxian and Fushun basins as typical examples to study the coal and oil shale sedimentary mechanisms controlled by the boundary fault. We found that the sedimentary mechanisms are different in different stages during the process of basin evolution. In the early stage, the association of coal and oil shale with thinner layers can be found. In the late part of early stage, thick layer coal seams and oil shale can be formed because of the relative stable faults. In the middle stage, thicker oil shale can be formed in deep lake and thicker coal seams can be formed in the lacustrine shore. In the late stage of basin evolution, the association of thickest coal seams and oil shale can be formed as the stable tectonic environment. Compared with the depression basin, more active fault and short cycle subsidence controlled by the episodic tectonic movements are the obvious characteristics. Higher rate of tectonic subsidence and a vast difference between sedimentary (peat-bearing) supply rate and accommodation space change rate are in favor of forming oil shale, and slower rate of tectonic subsidence is favor of forming coal. The study found that faulted structures obviously control the development, thickness and distribution characteristics of oil shale and coal. As mentioned above, the episodic tectonic movement of continental rift basin controls the types and filling and evolution of deposits.
\end{abstract}

Keywords: Coal seam, fushun basin, graben basin, huangxian basin, oil shale.

\section{INTRODUCTION}

Coal and oil shale are main fuels to be used for generating electricity and refinery, etc. Nowadays, there are a lot of coal or oil shale mines that make use of a single mineral. But when the people are mining the coal seams or oil shale, they found coal seams and oil shale were present in the same basin [1-6]. And most of basins are rift basins controlled by one or two faults, such as the Fushun Basin [3, 7], Huangxian Basin [4, 5, 8], Songliao Basin [9], Ethiopia 's Delbi-moye Basin $[1,2]$, Mae Sot Basin, Thailand [6], etc. Coal is formed from peat swamps in shallow water plant where plants were abundant. But the oil shale is formed from the algae in the deep lacustrine environment. It is shown that the abrupt environment change is present when the coal and oil shale were found in the same succession, especially in graben basins. The depositional conditions of graben basin are different from each other. A few layers of thick oil shale and coal beds can be found in some graben basins, while many layers of thinner oil shale and coal beds develop in some graben basins. There are some sedimentary differences among these basins which controlled the oil shale and coal depositions. So, it is necessary for us to observe these differences.

\footnotetext{
*Address correspondence to this author at the 579 Qianwangang Road Economic \& Technical Development Zone, Qingdao Shandong Province, 266510 P.R. China; Tel: +86-053286057229; E-mail: lvdawei95@163.com
}

There are many graben basins with coal bed- and oil shale-bearing succession in the eastern China. Many geological work have been finished in these area. There are many geological data in these basins. Currently, the research on coal and oil shale association rock series was mainly focused on hydrocarbon potential [9], organic geochemistry $[8,10,11]$ and paleo-environmental evolution $[1,3,9,11]$, etc. as there was lack of attention on the tectonic setting of the basin and dynamics of deposited systems $[12,13]$, especially in structure -deposition systems. However, the tectonic activities that control depositions are the key roles in oreforming processes in rift basins. Therefore, the study of overall tectonic sedimentary background and dynamic mechanism in rift basins is important for coal and oil shale exploration.

Huangxian basin has been influenced by sea water in the Paleogene period and developed many thin layers of coal and oil shale beds $[14,15]$. Fushun basin is an interior lake in the same period with a few thick layers of coal and oil shale beds $[18,19]$. These two basins can be typical basins each of which is the standard basins. So in this paper, we focus on study of the tectonic conditions and sedimentary cycles through the comparison between Huangxian and Fushun Basin, to explain the sedimentary mechanisms of coal and oil shale formations. 


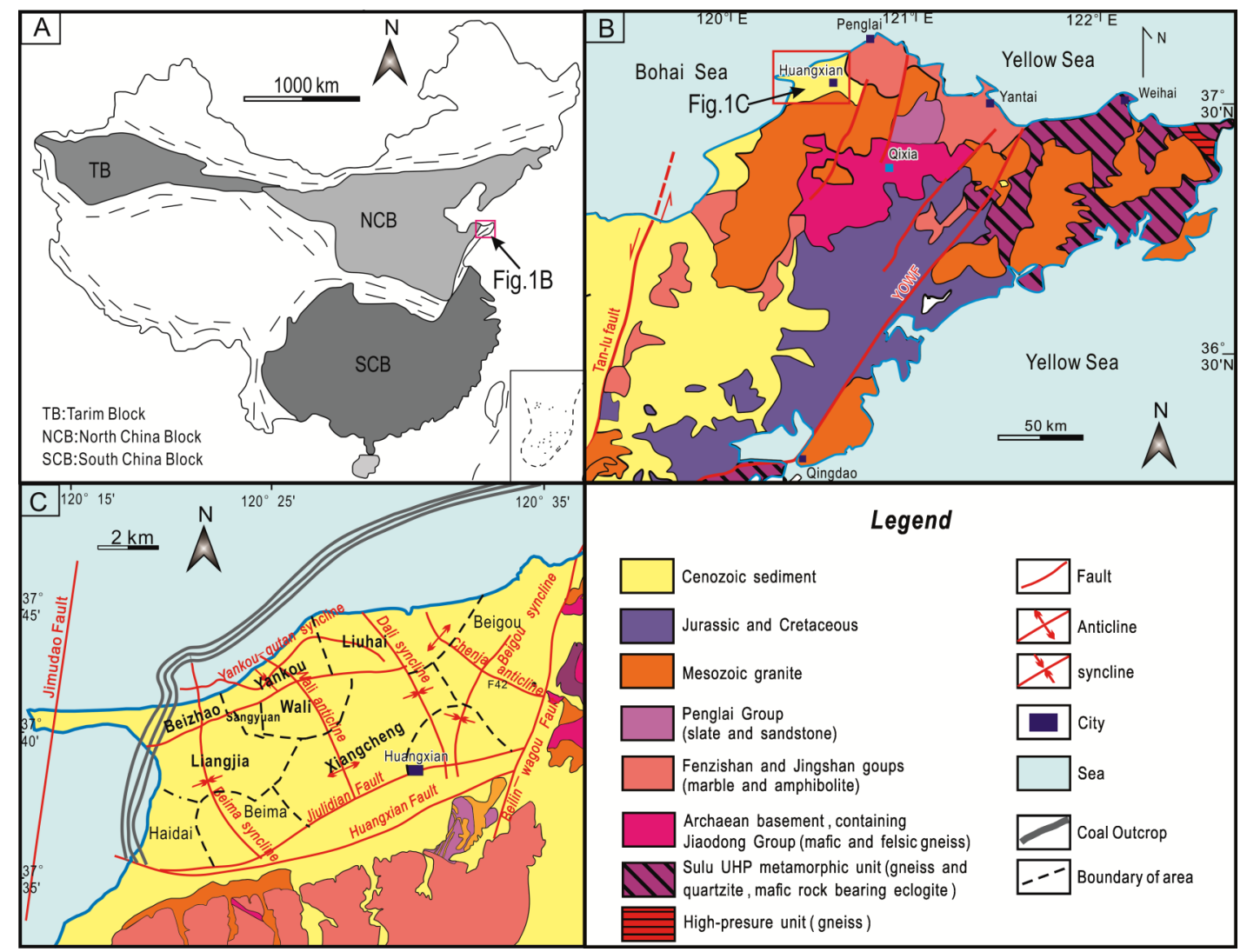

Fig. (1). Geological picture of Huangxian Basin.

\section{COAL AND OIL SHALE TECTONIC-DEPOSITON CHARACTERISTICS}

\subsection{Huangxian Basin}

Located in northeast of Shandong Province of eastern China, Huangxian Basin is a typical Paleogene offshored continental facies fault basin with coal and oil shale association succession. The development of the paragenetic association between coal and oil shale rock series is controlled by tectonic evolution and seawater intrusion. HuangxianDaxindian Fracture in south of Huangxian Basin and the east side of Beilinyuan -Wagou Fracture are the syndepositional fracture in Huangxian Group (Fig. 1). Huangxian - Daxindian Fracture in southern and Beilinyuan -Wagou Fracture in eastern are the key structures in Huangxian Basin. These fractures are formed in Late Mesozoic and show great activities in Paleogene, they are controlled by the formation and filling evolution of Huangxian Basin [14, 15]. The evolution of the Huangxian Basin can be divided into three tectonic evolution stages (Fig. 2):

\section{(1) Early Riftogenesis Stage}

There are a large scale of faults named HuangxianDaxindian Fracture which are formed in the Late Mesozoic to control the Huangxian Basin filling deposition. It shows strong activity $[16,17]$ in the Cenozoic in the edge of basin. In the south of fracture, there are the Linglong and Yanshan granite of Proterozoic. Beilinyuan -Wagou Fault, formed in the Mesozoic and showing strong activity in the Cenozoic, lying in the eastern boundary of basin. So, it also controls the edge fracture of sedimentary rift of Huangxian.
The prototype of fault depression basin of Huangxian was formed by the early riftogenesis process in the Paleogene period, because of the different terrain of both sides of fracture, the basin depositions are mainly small-scale alluvial fan deposition. With the strengthening of riftogenesis process, it gradually forms the large-scale alluvial fan to braided stream deposition called alluvial deposition system; the shore shallow lake deposition is developed in the areas of lacking alluvial deposition system, and shallow lake deposits in the central basin. In this period, strata thickness is about 50 meter without coal, oil shale or fossil. These deposits are the foundation for filling deposition of Huangxian graben basin.

\section{(2) The mature stage}

The mature stage of basin can be reflected by two big tectonic sedimentary cycles, each of which has coal seams and oil shale. Coal and shale accumulating stage can divide three sub stages. The first sub stage is the initial intense activity of basin edge faults, making the basin edge slope to increase, which make alluvial fan-fan delta to develop. During the second sub stage, the oil shale was formed through the transgression, and the lake was filled by deep lacustrine mudstone. The plants can grow in the hollow part of shore shallow lake. Relatively thicker coal seams transformed from peat swamp can be formed when the lake becomes shallow. The third sub stage is the relative steady sub stage, when the oil shale was formed and the basin began to shrink. Small thickness oil shale can be formed under the suitable climatic conditions. In the deep and expansion stage of basin, the basin water gradually expanded (water transgression) with 


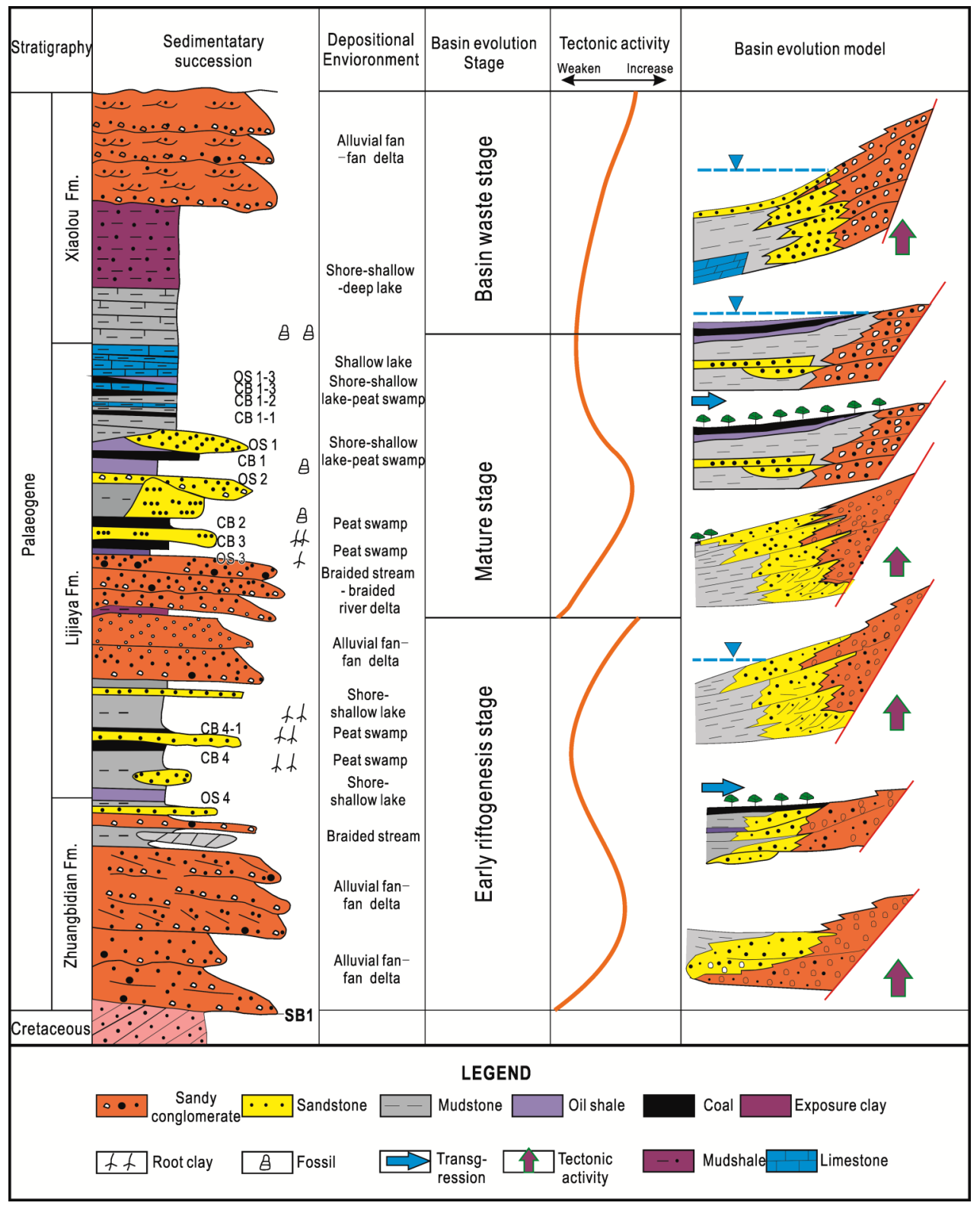

Fig. (2). Sedimentary evolution of Huangxian Basin in Paleogene.

little elevation difference of basin margin between the lateral uplift area (denudation area) and the inside of the basin edge area.

\section{(3) Basin waste stage}

During the basin waste stage, there are mainly developed alluvial deposits in basin. Alluvial - river reworked for the large-area weathering exposed surface exposure. In this stage, sedimentary upside shows more than $40 \mathrm{~m}$ of red sandstone with a thin layer of clay rock deposit without coal seams and oil shale. The late Himalayan movement made whole basin uplift, suffered erosion and formed plane of unconformity between Paleogene and Neogene strata.

\subsection{Fushun Basin}

Fushun Basin is located in Liaoning Province of northeast China (Fig. 3). The Paleogene strata with coal seam and oil shale can be divided into the Laohutai, Lizigou, Gu- chengzi, Jijuntun and Xilutian Formations. The oil shale can be found in Jijuntun Formation, while coal seams in $\mathrm{Gu}-$ chengzi Formation [18, 19].

There are different associations of coal and oil shale in Fushun Basin. The coal and oil shale-bearing successions were made by Laohutai, Lizigou, Guchengzi Formations with super thick coal seam, Jijuntun Formation with super thickness oil shale layer, Xilutian Formation with green shale section and other components from bottom to top. The huge thick oil shale layer was found on the coal seam and below the green shale layer. The study of contemporaneous structure of Fushun Basin through balanced cross section showed that it is the very strong taphrogeny [20-22] above the Cretaceous basement in the sedimentary period from Laohutai Formation to Xilutian Formation. According to developmental features of the stratum, the rifting process of this district can be divided into six stages (Fig. 4) which are as follows: 


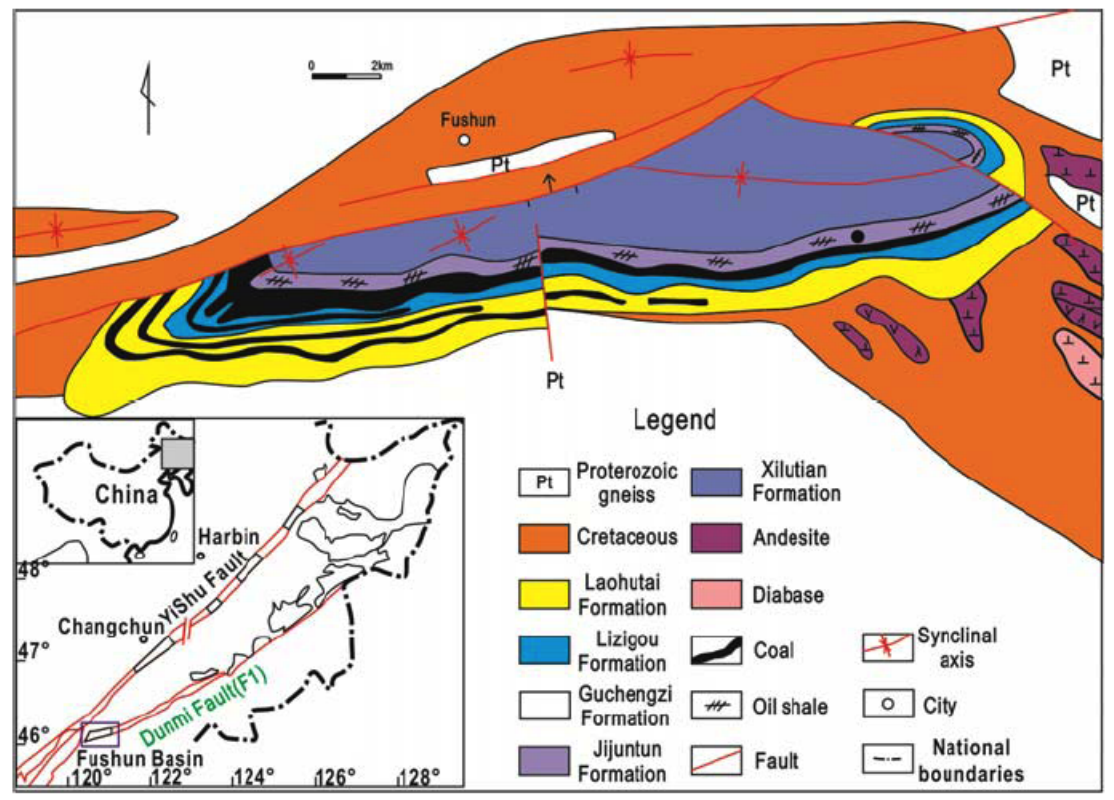

Fig. (3). Geological picture of Fushun Basin.

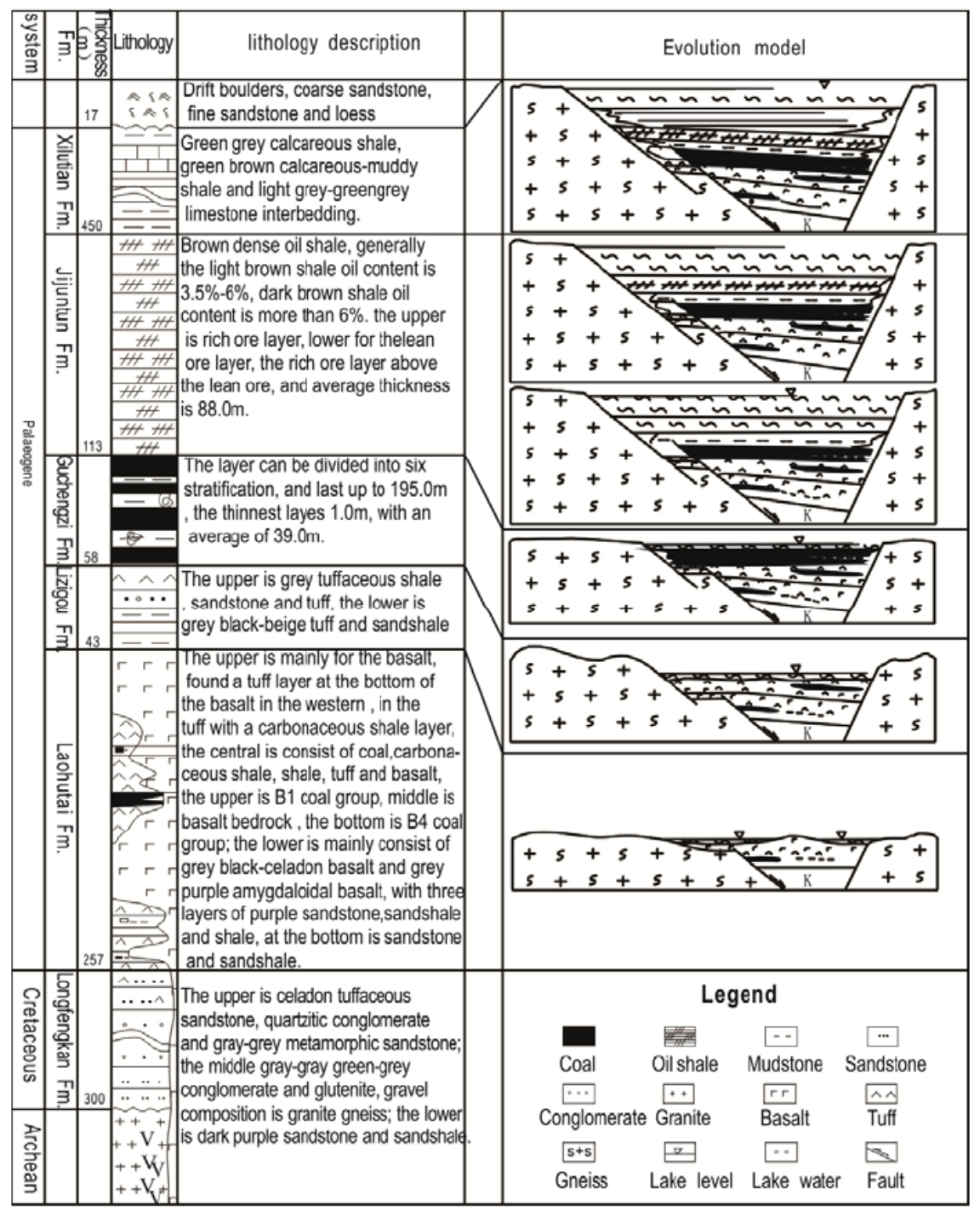

Fig. (4). Sedimentary environment model of Fushun Basin (Liu et al., 2009, modified). 
(1) The first one is initial rifting stage (the forming period of Laohutai Formation) when basement started to detach as a chasm and triggered basic magma eruption which induced synsedimentary faults. The study area was in a volcanic depression environment, and formed a filling construction dominated by basalt, tuff, sandstone and arenaceous shale. Peat bogs were formed in local area, which were saved as coal seams.

(2) The second stage was the accelerating rifting stage (formation period of the Lizigou Formation), during which time the basement's detachment as a chasm was accelerating, and basic magma eruption had ceased, which induced more synsedimentary fault activities. The area was in an intermountain lake basin environment, and formed a stratum which was dominated by tuff, sandstone, and nacreous shale. Peat bogs were formed in the local area, which were preserved as coal seams.

(3) The third one is the stable development stage (the forming period of Guchengzi Formation) when amplitude of basement detached as a chasm was smaller and most of the synsedimentary fault activity was less which induced the basin margin deplanation. Early tuff deposits compensated the basin depression and low-lying areas. The lack of periphery provenance supply, the weak longlasting synsedimentary fault and peat bog in the basin is usual. For the long period of bog's stable development, it formed a thick seam of high industrial value.

(4) The forth one is rapid rifting stage (the poor quality oil shale forming period of Jijuntun Formation) when basement detached as a chasm was fast and most synsedimentary fault was remain active with the higher deplanation degree of basin margin. The provenance supply was very little, so shallow lake-semideep lake was the main depositional environment. At this time, because of relatively fast settlement of basin basement, it had a relatively large sediment accumulation rate and a lower proportion of organic matter accumulation, therefore, poor quality shale layer was formed.

(5) The fifth one is relatively slow rifting stage (better quality layer oil shale forming period of Jijuntun Formation) when the basement detached as a chasm started to slow down and most of the syn-depositional fault gradually weakens. In this stage, basin basement subsidence rate was relatively slow with the high deplanation degree of basin margin and poor provenance supply, so the deep lake was the main depositional environment with the higher accumulation ratio of organic matter, the better quality oil shale layer with high oil content is formed in the long-term stability of deep lake environment.

(6) The last one is termination crack stage (green shale and marl forming period of Xilutian Formation) when the basement detached as a chasm terminated and synsedimentary faulting gradually finished. The climate is translated into half-dry-hot so that the lake salinized to an extent to form the half-salinized shallow lake environment intermittently. There are green calcareous shale, marlstone, and oil shale deposit in the deposition of the basin.

\section{DISCUSSIONS}

The sedimentation of fault basin was mainly controlled by basin-marginal synsedimentary faults. The development and evolution of the basin-controlled fault not only dominate the tectonic subsidence and the evolution of the sedimentary space of the basin, but also controlled the lateral migration development of the subsidence centers and sedimentary bodies, the different ancient landform between the provenance area and the sedimentary area. Therefore, the boundary fault of the fault basin had an obvious control on sedimentary process, it played an important effect on lithology, lithofacies combination and spatial distribution of the sediment.

In the early part of the forming stage of the graben basin, the sedimentary space of the basin was small, the main sedimentary types were coarse fragmental alluvial fan and fluvial facies. In this period, a few thinner layers of coal seam can be formed but oil shale can be formed usually due to the shallow water. With the strengthening of rifting, tectonic subsidence rate increased and the accommodation space enlarged, it gradually formed fan-delta, braided river delta, littoral and shallow lake sedimentary types. The cyclical upturn and downturn of tectonics in this period led to rapid change in sedimentary environment; as a result, it continuously developed sediments with totally different sedimentary environment and developed a variety of combination with coal and oil shale.

Along with the development of fault-controlled basin and sedimentation, fault throws gradually accumulated in the bottom of the fault, and sediment filled the downthrown side of the fault. During the stable subsiding stage of the basin, the central area of the basin gradually went into the half deep lake - deep lake sedimentation, coal accumulation effect in this period can only be greater than the area around the lake with shallow water, but the lake district with deep water developed some deep-water sedimentary oil shale, and only in the shore shallow lake area and the associations with coal and oil shale was possible. After the stable sedimentary period, due to the tectonic uplifting or excessive filling, lake water became shallow, the range of lake became smaller and gradually transited to a shallow lake, and the development range of oil shale in the lake became smaller. In this period, the coal formation process of the shore and shallow lake migrated to the middle of the lake, under the background of rapid tectonic uplifting, lake water rapidly became shallow, and coal seam may have directly developed on the top of oil shale and formed the associations with coal seams and oil shale. After that, the basin-controlled fault became more stable, and the basin filling was continually ongoing, or tectonics continuously uplifted, as a result, the lake gradually atrophied and finally died.

In short, the association with coal and oil shale can be found in the early development of the graben basin with thinner layers of coal seams and oil shale and limited distribution range. As the tectonic activity became less frequent, the relative thick layers of coal seams and oil shale can probably form. In the stable sedimentary period of the basin, it was easy to form relative thicker layers of oil shale in the lake district and thicker coal layer in the shore district because of the deeper water. The associations' distribution of coal seam and oil shale was limited. During the late stage of basin evolution, structure activity was relatively less, the associations of coal seams and oil shale are formed usually but with less layers. So we can find that the activity of the 
Table 1. Correlation analysis between Huangxian and Fushun basins.

\begin{tabular}{|c|c|c|c|c|c|c|}
\hline Basin names & Age & Evolution stage & Sedimentary evironment & $\begin{array}{c}\text { Tectonic } \\
\text { movement }\end{array}$ & Coal & Oil shale \\
\hline \multirow{3}{*}{$\begin{array}{l}\text { Huangxian } \\
\text { basin }\end{array}$} & \multirow{3}{*}{ Paleogene } & Basin waste stage & lacustrine-river & stable & none & obvious \\
\hline & & Mature stage & $\begin{array}{l}\text { shore lake, shallow lake, braided river } \\
\text { delta }\end{array}$ & stable & obvious & obvious \\
\hline & & Early riftogenesis stage & Fan delta, braided river & strengthen & very little & obvious \\
\hline \multirow[b]{3}{*}{ Fushun Basin } & \multirow[b]{3}{*}{ Paleogene } & relatively slow rifting stage & deep lake & stable & none & obvious \\
\hline & & rapid rifting stage & shallow lake-semideep lake & strengthen & none & obvious \\
\hline & & stable development stage & lacustrine peat bog & stable & obvious & none \\
\hline
\end{tabular}

master fault plays a major role in controlling of basin filling, sedimentary type and lithofacies distribution. During the stage with more fault activities, the accommodation space of the basin was large which was suitable for the development of oil shale and local area was suitable for the formation of peat swamp. In the steady subsidence stage of the fault, there are better sustainable sediment filling which is suitable for the formation of associations of coal and oil shale. In the stable period of the fault, peat swamp was mainly formed in the basin edge, while oil shale in basin center. The conclusion is summarized in Table $\mathbf{1}$.

\section{CONCLUSION}

(1) The boundary faults of graben basins mainly control the mineralization of coal seams and oil shale. The associations of coal and oil shale could be observed in the early stage of basin filling with thinner layers coal seams and oil shale and the limited distribution. In the period of rapid subsidence, the associations of coal seams and oil shale are formed usually because of oscillatory activity of structure. With the tectonic activity gradually stabilized, the frequency of tectonic activity became less, it could form the coal and oil shale beds and thickness was relatively greater. In the stable period of deposition, the structure was flat, and the depth of water was generally larger. Thicker oil shale beds were easy to grow in the lake, and thicker coal seams were easy to grow in the lakeside, and the range between them was limited. In the late period of basin evolution, the structure was relatively stable and the thicker associations of coal and oil shale could be formed, but it appeared less frequently.

(2) Compared with the depression basin, more active fault and short cycle subsidence controlled by the episodic tectonic movements are the obvious characteristics. Higher rate of tectonic subsidence, and a vast difference between sedimentary (peat-bearing) supply rate and accommodation space change rate are in favor of forming oil shale, and slower rate of tectonic subsidence favors the coal formation. The study found that faulted structure and the fracture structure obviously control the development, thickness and distribution characteristics of oil shale and coal. From the above mentioned text the episodic tectonic movement of continental rift basin controls the types, filling and evolution of deposits.

\section{CONFLICT OF INTEREST}

The authors confirm that this article content has no conflict of interest.

\section{ACKNOWLEDGEMENTS}

This work was financially supported by the National Natural Science Foundation of China (41272172, 41202070), the Research Fund for the Doctoral Program of Higher Education of China (20123718110004), Natural science Fundation of Shandong Province (ZR2015JL016) and the Shandong Provincial Key Laboratory of Depositional Mineralization \&Sedimentary Mineral (DMSM201401).

\section{REFERENCES}

[1] A. Wolela, "Sedimentology, depositional, environments and basin evolution of coal and oil shale-bearing sediments in the DelbiMoye Basin, Southwestern Ethiopia", SINET: Ethiopian Journal of Science, vol. 27, pp. 45-60, October 2004.

[2] A. Wolela, "Sedimentation, organic maturity, and petroleum potential of the Oligocene-Miocene oil shale deposits, Yayu Basin, southwestern Ethiopia”, AAPG Bulletin, vol. 94, pp. 643-663, December 2010.

[3] Q.T. Meng, Z.J. Liu, and A.A. Bruch, "Palaeoclimatic evolution during Eocene and its influence on oil shale mineralization, Fushun basin, China", International Journal of Coal Geology, vol. 45, pp. 95-105, January 2012.

[4] Z.X. Li, J.C. Wei, and S.C. Li, "The basin-filling features and sequence division in the Paleogene Huangxian fault basin, Shandong", Lithofacies Palaeogeography, vol. 18, pp. 1-8, June 1998.

[5] Z.X. Li, J.C. Wei and H.X. Lan "The high-resolution sequence division in Paleogene faulted basin of Huangxian", Coal Geology of China, vol. 12, no. 1, pp. 9-12, July 2000

[6] J.A. Curiale, and M.R. Gibling, "Productivity control on oil shale formation-Mae Sot Basin, Thailand", Pergamon, vol. 21, pp. 6789, January 1994. 
[7] G.F. Hou, Q.S. Dong, and W.B. Yu, "Geological characteristics and the ore forming process of the oil shale in the Fushun Basin", Journal of Jilin University, vol. 36, pp. 991-995, June 2006.

[8] Y.Z. Sun, B.S. Wang, and M.Y. Lin "Maceral and geochemical characteristics of coal seam 1 and oil shale 1 in fault-controlled Huangxian Basin, China", Organic Chemistry, vol. 29, pp. 583591, March 1998.

[9] A. Bechtel, J.L. Jia, and S.A. Strobl, "Palaeoenvironmental conditions during deposition of the Upper Cretaceous oilshale sequences in the Songliao Basin (NE China): Implications from geochemicalanalysis", Organic Geochemistry, vol. 46, pp. 76-95, February 2012.

[10] B. Follows, and R.V. Tyson, "Organic facies of the Asbian (early Carboniferous) Queensferry Beds,Lower Oil Shale Group, South Queensferry, Scotland, and a briefcomparison with other Carboniferous North Atlantic oil shale deposits", Organic Geochemistry, vol. 29, pp. 821-844, August 1998.

[11] A.R. Cameron, F. Goodarzi and J. Potter, "Coal and oil shale of Early Carboniferous age in northern Canada:significance for paleoenvironmental and paleoclimateic interpretations", Palaeogeography, vol. 106, pp. 135-155, February 1994.

[12] Z.J. Liu, Q.T. Meng and R.Liu "Geochemical of oil shale of Eocene Jijuntun Formation and its geological significance, Fushun Basin", Acta Petrologica Sinica, vol. 25, pp. 2340-2350, June 2009.

[13] R.C. Milici, G. Briggs, and L.M. Knox, "Mississippian and Pennsylvanian (Carboniferous) Systems in the United States: Tennessee”, US Geological Survey, Professional Papers, 1110-A-L, 1979.
[14] Z.F. Wang, M.Y. Li, and B.S. Wang, "Maceral and geochemical characteristics of coal seam and oil shale in Huangxian Basin", Coal Geology \& Exploration, vol. 35, pp. 12-14, July 2007.

[15] J.C. Wei, Z.X. Li and S.C. Li "Basin-Filling Evolution and Coal Accumulationin Huangxian Faulted Basin", Journal of China University of Mining \& Technology, vol. 29, pp. 300-305, February 2000.

[16] B.S. Wang, Y.H. Li, and X. Wang "Palaeogen trangressive lacutrine environment and coal accumulation in Huangxian Basin", Coal Geology \& Exploration, vol. 28, pp. 8-11, August 2000.

[17] B.S. Wang, J.F. Yu, and Y.Z. Sun, "Analysis on peat swamp types from Huangxian Tertiary brown coal and oil shale bearing basin", Coal Geology \& Exploration, vol. 29, pp. 1-3, January 2001.

[18] F. Liu, Z.J. Liu, and R. Liu, " Geochemistry of oil shale from Jijuntun Formation of Eocene in Fushun Basin and its depositional environment", Global Geology, vol. 26, pp. 441-446, September 2007.

[19] S.C. Xu, Z.J. Liu, and Q.S Dong, "Eocene sedimentary evolution and its control over coal \& oil shale development in Fushun Coalfield", Journal of China University of Petroleum, vol. 36, pp. 45-67, November 2012.

[20] C.L. Wu, X.Q. Wang and G. Liu, "The dynamics of tectonic evolution in Fushun Basin", Science in China, vol. 31, pp. 477-485, September 2001

[21] F.G. Hou, Q.S. Dong, and W.B. Yu, "Geological characteristics and the ore- forming process of the oil shale in the Fushun Basin", Journal of Jilin University, vol. 36, pp. 991-995, May 2006.

[22] Z.J. Liu, Q.T. Meng, and R. Liu, "Characteristics and genetic types of continental oil shale in China", Journal of Palaeogeography, vol. 11, pp. 105-114, April 2009.

Received: January 14, 2015

Revised: May 15,2015

Accepted: July 07, 2015

(C) Lv et al.; Licensee Bentham Open.

This is an open access article licensed under the terms of the (https://creativecommons.org/licenses/by/4.0/legalcode), which permits unrestricted, noncommercial use, distribution and reproduction in any medium, provided the work is properly cited. 